\title{
Consumption of Alcohol and Drugs in the School Population of Sao Tome and Principe
}

\section{Consumo de Álcool e Drogas na População Escolar de São Tomé e Príncipe}

Isabel DE SANTIAGO ${ }^{1}$, Ruy RIBEIRO ${ }^{2}$, Leonor Bacelar NICOLAU ${ }^{3}$, Rui Tato MARINHO ${ }^{4,5}$, José PEREIRA-MIGUEL ${ }^{6}$ Acta Med Port 2020 Apr;33(4):237-245 - https://doi.org/10.20344/amp.11876

\begin{abstract}
Introduction: In Sao Tome and Principe there are no studies on alcohol and drug use among students, who could be potential allies in preventive interventions. The objectives of the present study are 1) to determine the frequency of alcohol and drug consumption in the school population, and 2) to identify the main characteristics associated with this behaviour.

Material and Methods: We applied a biographical, demographic and socioeconomic questionnaire on the use of licit and illicit substances to a sample of 2064 students. Demographic and social characteristics are presented based on observed frequencies and comparisons between groups were made using chi-square tests. Significance was assessed at $\alpha=0.05$.

Results: More than half of the students reported consumed alcohol at least once in their lifetime, and $32 \%$ consumed in the last 30 days. Older students were more likely to consume alcohol $(p<0.0001)$, but even in students under 16 years, $17 \%$ consumed in the last 30 days. We also found that $7 \%$ consumed one or more times per week in the last 30 days. The reasons presented for frequent consumption were different for boys ("participation in their group of friends") and girls ("decrease anxiety") $(p=0.005)$. Less than $1 \%$ of respondents admitted to having used marijuana, cocaine, crack or ecstasy.

Discussion: Despite some limitations, such as self-reporting, we provide a first overview showing high consumption of alcohol by young people and the existence of illegal drugs circulating in the schools.

Conclusion: It is urgent to implement preventive interventions, namely in the context of public health communication

Keywords: Adolescent Behavior; Atlantic Islands; Alcohol Drinking; Drug Users; Illicit Drugs; Students
\end{abstract}

\section{RESUMO}

Introdução: Em São Tomé e Príncipe não há estudos sobre o uso de álcool e drogas na população escolar, potencial aliada em intervenções preventivas. Os objetivos do presente estudo são 1) determinar a frequência do consumo de álcool e drogas na população escolar e 2) identificar as principais características associadas a estes comportamentos.

Material e Métodos: Foi aplicado um questionário biográfico, demográfico e socioeconómico sobre o uso de substâncias lícitas e ilícitas para uma amostra de 2064 alunos. As características demográficas e sociais apresentadas baseiam-se nas frequências observadas e as comparações entre os grupos foram feitas usando testes de qui-quadrado. A significância foi avaliada em $\alpha=0,05$.

Resultados: Mais de metade dos alunos referiram consumir álcool pelo menos uma vez na vida, e $32 \%$ nos últimos 30 dias. Os alunos mais velhos mostraram-se mais propensos a consumir álcool $(p<0,0001)$, mas mesmo nos alunos com idade inferior a 16 anos, $17 \%$ consumiram nos últimos 30 dias. Constatou-se também que entre todos os alunos, $7 \%$ consumiram uma ou mais vezes por semana nos últimos 30 dias. As razões apresentadas para o consumo frequente foram diferentes para os rapazes ("participação no grupo de amigos") e raparigas ("diminuição da ansiedade") ( $(p=0,005)$. Menos de $1 \%$ dos entrevistados admitiram ter usado maconha, cocaína, crack ou ecstasy.

Discussão: Apesar de algumas limitações, como o auto reporte, publica-se um primeiro diagnóstico de situação mostrando um elevado consumo de álcool pelos jovens e ainda a utilização de drogas ilegais nas escolas.

Conclusão: É urgente o desenvolvimento de intervenções preventivas, nomeadamente, no âmbito da comunicação em saúde pública. Palavras-chave: Comportamento do Adolescente; Consumidores de Droga; Consumo de Bebidas Alcoólicas; Drogas llícitas; Estudantes; Ilhas Atlânticas

\section{INTRODUCTION}

African countries (AC) are mostly, low-and middle income countries (LMIC), where extreme poverty ${ }^{1,2}$ causes considerable health inequalities. ${ }^{3,4}$ Sao Tome and Principe (STP), the smallest of them, presents a socio-epidemiological reality ${ }^{5}$ characterized by the lack of healthy lifestyles, ${ }^{6,7}$ formal education and health communication policy. ${ }^{7-10}$ No systematic research has been done on the consumption of alcohol and drugs in STP, and only overall statistics are available based on the importation of alcoholic drinks and

their distribution among the population., ${ }^{8,11}$ In fact, the World Health Organization (WHO) "Global Status Report on Noncommunicable Diseases 2014" is the only survey ${ }^{12}$ in Africa dealing with $A \& D$ consumption and its harmful use, but it presents only aggregated data.

According to the WHO, alcohol use results in 3.3 million deaths globally. ${ }^{7}$ Heavy consumption of alcohol, an oncogenic substance, is believed to be a risk factor for cancer ${ }^{13-16}$ due to more than a hundred medical outcomes,

\footnotetext{
1. Comunicação em Saúde Pública. Instituto de Medicina Preventiva e Saúde Pública. Faculdade de Medicina. Universidade de Lisboa. Lisboa. Portugal.

2. Laboratório de Biomatemática. Instituto de Medicina Preventiva e Saúde Pública. Faculdade de Medicina. Universidade de Lisboa. Lisboa. Portugal

3. Economia da Saúde. Instituto de Medicina Preventiva e Saúde Pública. Faculdade de Medicina. Universidade de Lisboa. Lisboa. Portugal.

4. Serviço de Gastrenterologia e Hepatologia. Hospital Universitário de Santa Maria. Centro Hospitalar Universitário de Lisboa Norte. Lisboa. Portugal.

5. Department of Gastroenterology and Hepatology. Faculdade de Medicina. Universidade de Lisboa. Lisboa. Portugal.

6. Medicina Preventiva. Instituto de Medicina Preventiva e Saúde Pública. Faculdade de Medicina. Universidade de Lisboa. Lisboa. Portugal.

$\square$ Autor correspondente: Isabel De Santiago: isabeldesantiago@medicina.ulisboa.pt

Recebido: 01 de fevereiro de 2019 - Aceite: 22 de outubro de 2019 | Copyright @ Ordem dos Médicos 2020
} 
as well as a risk for other non-communicable diseases (NCD), ${ }^{7,17}$ such as mental and behavioral disorders, and it is also responsible for injuries, road traffic accidents $\mathrm{s}^{6,18-20}$ and deaths. ${ }^{21,22}$ Thus, the situation constitutes a serious threat to public health. ${ }^{3}$ It is difficult to judge the level of alcohol intake in STP, because the scientific community is often unaware of all types of artisanal alcohol (outside the commercial circuit) produced in STP ${ }^{23}$ (without regulatory legislation and no sanitary control) and consumed by local communities. ${ }^{24,25}$ For example, in STP, the most common forms of alcohol are cacharamba, chalelinha and tomatxo, a distilled drink (sugarcane, mango, cajamanga fruit and pineapple), and palm wine produced locally. The WHO estimates that, in 2014, this unrecorded consumption for people older than 15 years $^{11}$ in STP is $2.9 \mathrm{~L}$ per capita of the total $7.1 \mathrm{~L}$ per capita estimated for 2008 - 2010. Much heavier drinking habits are estimated in males (11.5 L per capita) compared to females $\left(2.9 \mathrm{~L}\right.$ per capita). ${ }^{11,19}$ The WHO also estimates that more females $(72.6 \%)$ than males $(50.6 \%)$ were abstainers in the last 12 months. ${ }^{26}$ However, there is no data specific to young people ${ }^{27,28}$ (school population) or on the effects of alcohol on NCD ${ }^{29,30}$ or deaths in STP. ${ }^{7,19,21}$

Young people are vulnerable $e^{6,26,31}$ to developing habits of harmful alcohol consumption, ${ }^{27,32-34}$ with important life-time implications for their health. The risk of future addiction is very high if 'binge' drinking begins at age 15 . In addition, some preventive interventions (health promotion and risk reduction $)^{35}$ to reduce the consumption of alcohol ${ }^{36-39}$ and drugs, ${ }^{27,38}$ such as health communication, ${ }^{40-43}$ are recommended for younger populations $\mathrm{s}^{44,45}$ as a health priority. ${ }^{46,47}$ As a basis to develop intervention priorities, the present study analysed the frequency and distribution of alcohol and drug consumption in the public-school population of STP, and identified and characterized the profile of consumers. ${ }^{48-50}$

\section{MATERIAL AND METHODS National survey}

We conducted a cross sectional, observational study with a questionnaire-based survey of the student population (public schools and university) of STP between September 2013 and May 2014. We interviewed a sample of students from three settings: grades eight to 12 in public secondary education; public university and night school; and professional and qualification training. We emphasize that typically these levels of education include students aged 12 - 18; 18 - 25; and older respectively. The anonymous questionnaire included biographic, demographic and socio-economic ${ }^{26,51}$ questions, as well as questions about the use of licit and illicit substances. ${ }^{38}$ The survey instrument was developed specifically for this study, in Portuguese language adapted to the local dialect Forro. The questionnaire was first validated based on a pilot survey of a convenience sample of 150 male and female students, including analyses of comprehension of the questions and translation. This questionnaire is included in the Appendix (see Appendix 1: https:// www.actamedicaportuguesa.com/revista/index.php/amp/
article/view/11876/Appendix_01.pdf). For the main study, from the total population of 16924 students in public schools and the Instituto Superior Politécnico, now part of the University of Sao Tome and Principe, we obtained a sample of 2064 individuals $(12 \%$ of the total). This sample included students from all public schools of STP, and each school was sampled proportionally to its student population size. This sampling was done in coordination with the school's Principal and for each school, random classes, with approximately equal numbers of boys and girls, were chosen to answer the questionnaire, so in each school we sampled classes not students for logistical reasons. The students from the classes selected were instructed about the objectives of the study, the anonymity of the questionnaire and that they were not under any obligation to answer it or any of the questions. Thus, filling the anonymous questionnaire corresponded to informed consent. A sample with this size has associated a maximum error of estimation for the proportions analysed of $2 \%$, for a confidence level of $95 \% .{ }^{52}$

Approval by all relevant authorities of STP including the Ministry of Educação, Cultura e Formação and the Directorate of Ensino Secundário (Secondary Education) was obtained before application of the questionnaire. In addition, the study was approved by the Ethics Committee of Centro Hospitalar de Lisboa Norte, Faculdade de Medicina da Universidade de Lisboa and Centro Académico de Medicina de Lisboa (Reference number 47/16).

\section{Statistical analyses}

We present the results of descriptive statistical analyses of the data, and comparisons between groups that were done using chi-square test or Fisher exact test, if necessary. Since answering each question was optional, some of the variables may not have data for the full 2064 participants. In each figure, we present the number of respondents for the specific question being analysed. The analyses were done using IBM SPSS, 24 version. We considered a significance level of $a=0.05$.

\section{RESULTS}

\section{Overall alcohol consumption habits}

This study analysed the sociodemographic characteristics of the alcohol and drug consumption habits of the schoolaged population of the islands of STP. From the 2064 individuals surveyed, $52 \%$ were male and $48 \%$ were female. The age limits were 12 - 30, with a median of 18 years of age. We sampled students from all public schools in STP, including all districts (Fig. 1). The students were attending secondary school (56\%, median age $=17$, interquartile range $=3)$; night school and illiteracy classes $(30 \%, m=21$, IQR = 8); technical education $(9 \%, m=21, I Q R=4)$; and higher education $(5 \%, m=22, I Q R=5)$.

Half of the students admitted having consumed alcohol at least once in their lifetime (Fig. 2), 29\% consumed alcohol over the previous 30 days, with $22 \%$ stating that they consumed less than once a week and $7 \%$ once or more times per week (Fig. 3). In addition, $23 \%$ of students 


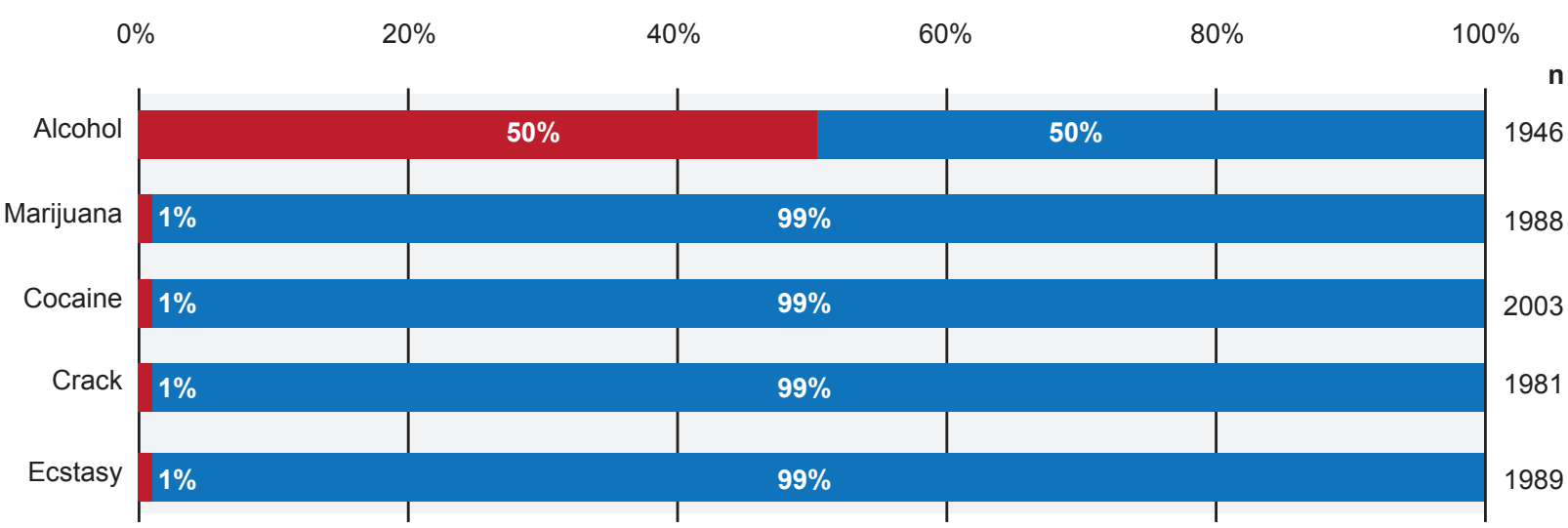

Figure 1 - Percentage of respondents admitting to having ever tried alcohol or illicit drugs

acknowledged that they have friends who get inebriated on a weekly basis, and of these, $1 / 3$ say that many or all of their friends do get inebriated.

\section{Demographic characterization of alcohol consumption}

We then analysed the demographic characteristics of alcohol consumption among the student population (Table 1). Overall, male students are more prone to drinking alcohol than female students, with $58 \%$ vs $43 \%$, respectively, saying that they did at least once in the past (Fig. 4). This difference was statistically significant $\left(\chi^{2}=42.55, p=7 \times\right.$ $\left.10^{-11}\right)$. The female students also reported drinking less frequently, with $25 \%$ stating that they consumed over the last 30 days, in comparison with $38 \%$ of male students doing so. However, if we focus only on these students who did consume over the last 30 days, the frequency $(<1 /$ week vs $\geq 1$ /week) of consumption does not reach statistical difference between males and females $(27 \%$ vs $20 \%$ consume $\geq$ $1 /$ week, respectively, $\chi^{2}=3.26, p=0.071$ ).

There was a very strong association between alcohol consumption and age $\left(\chi^{2}=176.96, p=2.4 \times 10^{-36}\right)$, with higher proportions of older students having tried alcohol before (we stratified age as in Fig. 4). But even in the two younger age groups (<14 years and $15-16$ ), about $35 \%$ indicated that they have consumed alcohol before, and $17 \%$ consumed over the last 30 days. Even though $69 \%$ of students older than 25 had consumed alcohol before, this was less than in the 20 - 25 age group (74\%), but this difference was not significant $\left(\chi^{2}=1.68, p=0.19\right)$. When we analysed only those who stated they had drunk alcohol in the last 30

How often have you consumed alcohol over the last 30 days? $\mathrm{n}=2064$

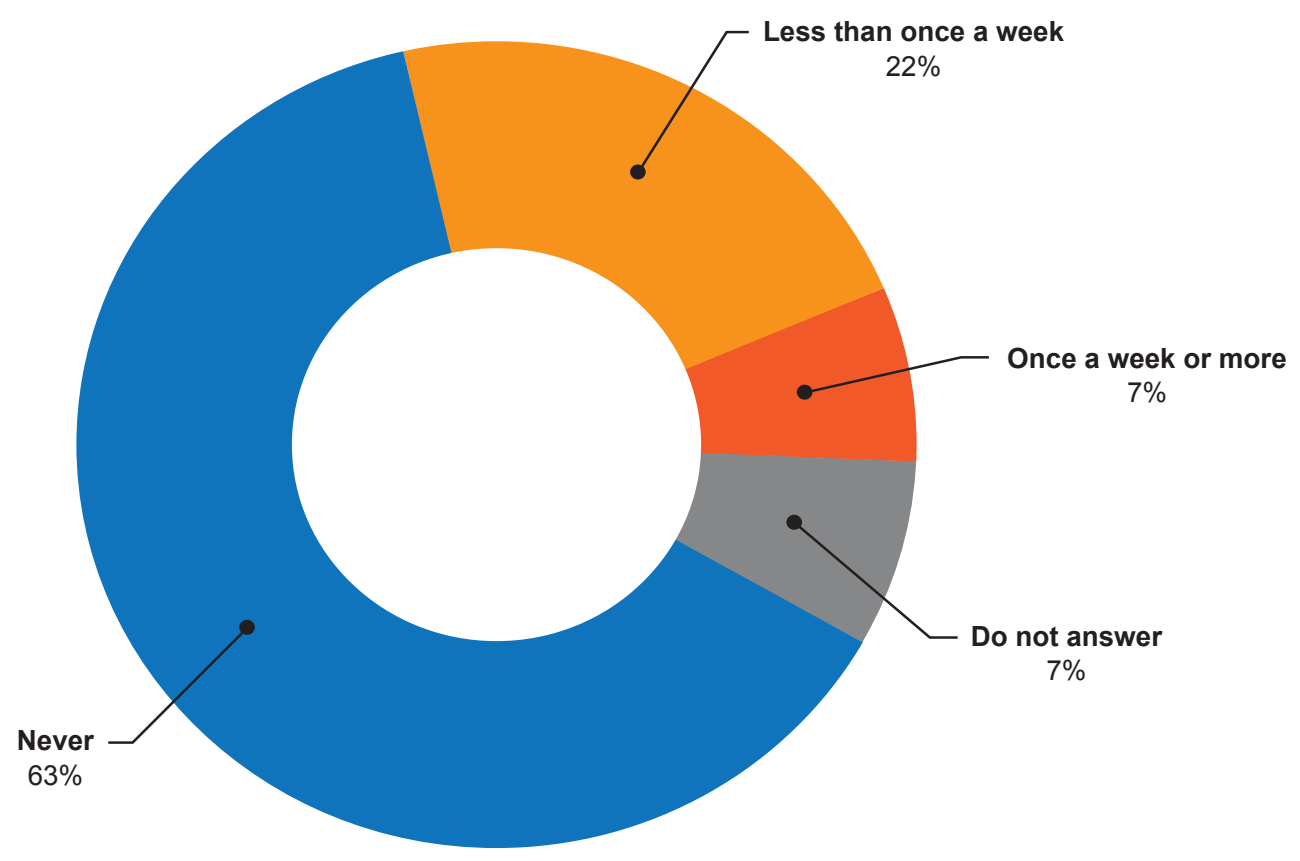

Figure 2 - Frequency of drinking in the last 30 days 


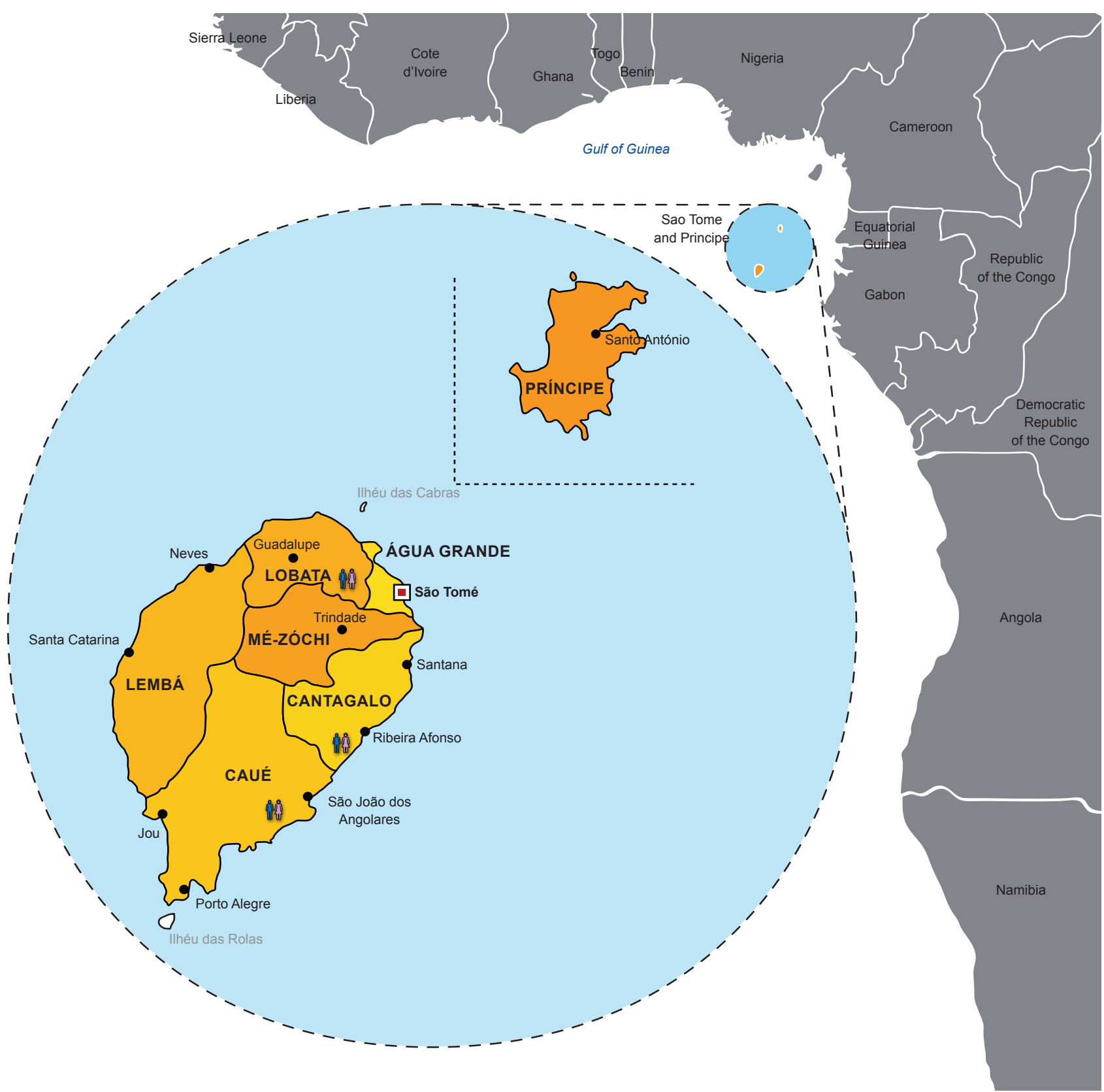

Figure 3 - Map of São Tome and Príncipe, highlighted on the African Coast, Gulf of Guinea, to allow identification of the provinces included in the present study (see Figure 4)

days, there was no association between age and drinking level ( $<1 /$ week or $\geq 1 /$ week $)\left(\chi^{2}=10.46, p=0.063\right)$. For example, for the ages between 15 and 25 , about $20 \%$ to $27 \%$ of those who drank in the last 30 days, did so frequently ( $\geq$ 1/week) (Fig. 4).

We also analysed the geographical disparities in alcohol consumption in STP (Figs. 1 and 4). We were especially interested to see any differences due to income levels in the different districts. However, we found that the highest levels of consumption were in Água Grande and Lembá, which are the richest and poorest districts of STP, respectively. In these districts, $56 \%$ and $57 \%$, respectively, of students reported drinking alcohol at least once before.

\section{Social characterization of alcohol consumption}

Students attending night school and literacy classes $(57 \%)$, technical training $(76 \%)$ and higher education $(79 \%)$ presented a higher proportion of having consumed alcohol before than students in regular day time high school $(40 \%)$ (Fig. 4). However, this may be related to the older age of students in those educational contexts. In fact, the median age of students in regular high school is 17 vs 21 in the other three types of educational setting. As expected, the frequency of drinking is also different with $5 \%$ of students in daytime secondary school affirming that they consumed more than once a week in the last 30 days, versus $11.3 \%$ for the students in the other educational settings. The mother's education level does not seem to influence past alcohol consumption: $49 \%$ of students with mothers lacking formal 
Table 1 - Analyses of the characteristics of the student population and their alcohol consumption habits (have you ever consumed alcohol?)

\begin{tabular}{|c|c|c|c|c|}
\hline Factor & & Yes & No & $p$-value \\
\hline \multirow{2}{*}{ Gender } & Male & 566 & 406 & \multirow{2}{*}{$7 \times 10^{-11}$} \\
\hline & Female & 385 & 510 & \\
\hline \multirow{6}{*}{ Age } & $\leq 14$ & 55 & 155 & \multirow{6}{*}{$2 \times 10^{-36}$} \\
\hline & $15-16$ & 150 & 233 & \\
\hline & $17-18$ & 279 & 334 & \\
\hline & $19-20$ & 154 & 92 & \\
\hline & $20-25$ & 208 & 72 & \\
\hline & $>25$ & 123 & 56 & \\
\hline \multirow{4}{*}{ Education } & Secondary school daytime & 448 & 659 & \multirow{4}{*}{$1 \times 10^{-28}$} \\
\hline & Night school and literacy & 318 & 241 & \\
\hline & Technical education & 138 & 43 & \\
\hline & Higher education & 78 & 21 & \\
\hline \multirow{7}{*}{ District } & Água Grande & 773 & 611 & \multirow{7}{*}{$1 \times 10^{-13}$} \\
\hline & Cantagalo & 13 & 34 & \\
\hline & Caué & 23 & 61 & \\
\hline & Lembá & 30 & 23 & \\
\hline & Lobata & 20 & 49 & \\
\hline & Mé Zochi & 95 & 132 & \\
\hline & Príncipe & 28 & 54 & \\
\hline \multirow{3}{*}{ Mother's education } & No formal education & 101 & 104 & \multirow{3}{*}{0.091} \\
\hline & First degree incomplete & 720 & 668 & \\
\hline & Higher education completed & 115 & 143 & \\
\hline \multirow{2}{*}{ Father consumes } & Yes & 425 & 337 & \multirow{2}{*}{0.0002} \\
\hline & No / Don't know & 557 & 627 & \\
\hline \multirow{2}{*}{ Mother consumes } & Yes & 309 & 216 & \multirow{2}{*}{$9 \times 10^{-6}$} \\
\hline & No / Don't know & 673 & 748 & \\
\hline
\end{tabular}

education have consumed in the past, compared with $52 \%$ of the children of mothers with the incomplete secondary cycle and $45 \%$ for the case of completed higher education $\left(\chi^{2}=4.79, p=0.091\right)$ (Fig. 3). The mother's education level was also not associated with the frequency of drinking $\left(\chi^{2}\right.$ $=6.49, p=0.165$, using three categories of drinking frequency none, $<1 /$ week and $\geq 1 /$ week). On the other hand, the actual alcohol/drug consumption habits of the mother or the father were associated with student drinking, with more of them having tried alcohol at least once if their mother or father are regular users $\left(\chi^{2}=19.81, p=9 \times 10^{-6}\right.$ and $\chi^{2}=13.79, p=0.0002$, respectively). Interestingly, this association does not affect students who drink regularly or heavily (more than once a week in the last 30 days), since about $7 \%$ - $9 \%$ report this behaviour, regardless of whether their father or mother drink regularly or not. The biggest difference is that substantially more students reported drinking occasionally (less than once a week over the last 30 days), if their mother or father also consumed.

When asked why they consume alcohol frequently, the 109 students, who admitted to that (and also answered this question), chose as the main reason "to participate in their peer group" (52\%), "to break routine or enjoy the effects" (19\%), "to relieve anxiety or stress" (26\%), and "to relief abstinence symptoms" (3\%). But these percentages were very different for males and females $(p=0.005$ by generalized Fisher test), with the former choosing the first reason $58 \%$ of the time versus $37 \%$ for girls, whereas females chose "relieving anxiety" $50 \%$ vs $17 \%$ for boys.

\section{Illicit drug consumption habits}

We also asked about consumption of illicit drugs, but very small numbers of students admitted to this, with $1 \%$ or less having tried marijuana, cocaine, crack and/or ecstasy before (Fig. 2). These small numbers do not allow us to characterize this behaviour in more detail.

\section{DISCUSSION}

Alcohol and drug consumption in the Republic of STP $^{11,26,53}$ is a potential public health problem. ${ }^{54-56}$ Excessive alcohol consumption can incur in high loss of life and Disability-Adjusted Life Years (DALY) ${ }^{5,17}$ particularly if there's lack of appropriate preventive interventions, ${ }^{57,58}$ such as legislation or public health communication preventive 
No

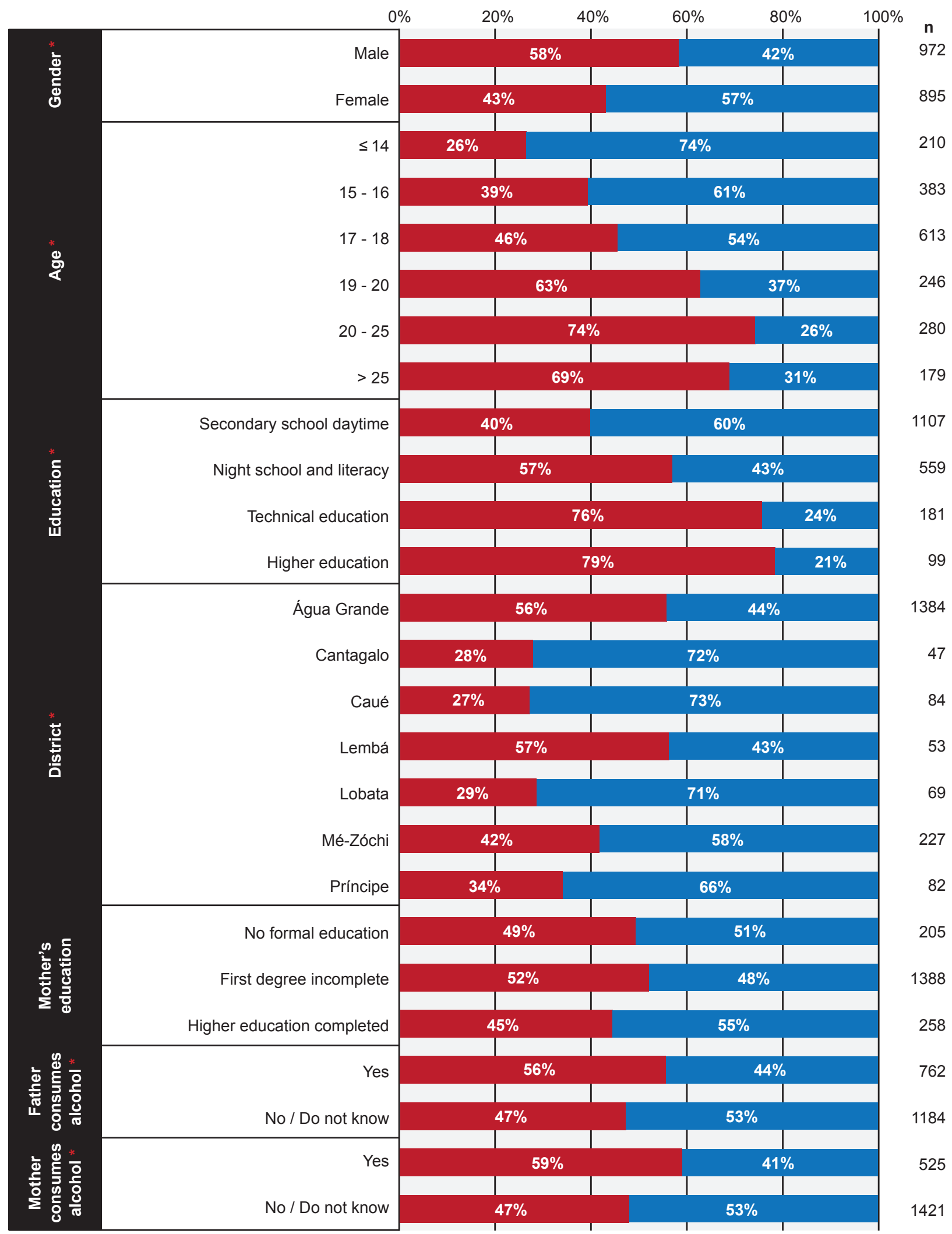

Figure 4 - Determinants of alcohol consumption among the school population in Sao Tome and Principe

${ }^{*}$ Chi-square test $p<0.05$ 
policies, ${ }^{59,60}$ or lack of social and health education ${ }^{31,62}$ and communication policies ${ }^{63}$ empowering students ${ }^{39,64}$ and youth in general for preventive behaviours. ${ }^{54,65}$ No legislation has yet regulated artisanal alcohols, ${ }^{31,61}$ produced in the community and sold freely to everyone.

In this study, we provide the first overview of the habits of alcohol and drug consumption in the school population in São Tomé. We found high levels of alcohol consumption, and a considerable proportion of regular drinkers ${ }^{19,31}$ $(\sim 30 \%)$. There were differences between males and females, and among age groups, in their lifetime consumption habits. However, when we focused only on those students who consumed alcohol in the last 30 days, differences by sex and age were much less evident. This may indicate that there is a group of regular consumers, who have different socio-demographic characteristics compared to the overall student population. Such a possibility should be taken into account when defining intervention strategies. ${ }^{28,34}$ The issue of a potential group of "regular consumers" is reinforced by our findings that heavy drinkers ${ }^{28}$ among the student population ${ }^{66}$ were not associated with the consumption habits of the parents, although general consumption habits of students (for example, being "occasional drinkers") were associated with the consumption behaviour of parents. Overall, we found low levels of admission of illicit drug consumption, but this study did confirm the existence of these drugs circulating within the school settings.

There are limitations to our study. The most important is that this is a voluntary self-assessment survey, since the students answered the questionnaire by themselves (albeit during class time). This could also mean that different students may have understood some questions differently. We tried to minimize these issues by explaining the questionnaire before ${ }^{67,68}$ students started answering it and assuring them of anonymity. Moreover, questions that could be subjective, like amount of drinking, were framed with specified frequency ranges [see questionnaire in the Appendix (https://www.actamedicaportuguesa.com/revista/ index.php/amp/article/view/11876/Appendix_01.pdf)]. However, we did not include an actual measure of quantity drunk (e.g., one cup or $150 \mathrm{~mL}$ ), because this would be difficult to interpret. Other context dependent issues that must be considered refer to questions about the drinking habits of family members. In STP, non-traditional family units are common, for example men can have more than one wife (polygamy).

In this study, we targeted the school population, because we believe they are a primary target for future health communication preventive intervention campaigns, but we acknowledge that there may be many young people not attending school. This population may be qualitatively different from the one surveyed in the study, and so we cannot extrapolate our findings to all the youth of STP.

\section{CONCLUSION}

Despite the aforementioned limitations, to our knowledge, a study of this kind has never been done in Portuguese-speaking African Countries, and so we provide a valuable assessment for STP. Clearly, there is a great need for further epidemiological research in developing African countries.

Altogether, we conclude that the prevalence of alcohol consumption identified among the school population is high, with significant rates of regular drinkers, but admission of drug consumption is relatively low. Consumption of both alcohol and drugs constitute a potential public health problem in STP.

\section{ACKNOWLEDGEMENTS}

We would like to acknowledge the logistical support of Diocese of São Tomé and Principe, Company of Santa Teresa of Jesus, Sao Tome and Principe, Delegate of Health, District of Lembá, President of autonomic Region of Príncipe and former Minister of Educação, Cultura e Formação of STP, currently the Prime Minister.

\section{PROTECTION OF HUMANS AND ANIMALS}

The authors declare that the procedures were followed according to the regulations established by the Clinical Research and Ethics Committee and to the Helsinki Declaration of the World Medical Association.

\section{DATA CONFIDENTIALITY}

The authors declare having followed the protocols in use at their working center regarding patients' data publication.

\section{CONFLICTS OF INTEREST}

All authors report no conflict of interest.

\section{FUNDING SOURCES}

Support was received from the Associação Nacional de Farmácias to attend two scientific conferences for presentation of results: at IUPHE Curitiba-Brazil in May 2016 and at the CDC in Atlanta-USA, August 2016.

\section{REFERENCES}

1. Marmot M, Allen J. Health priorities and the social determinants of health. East Mediterr Heal J. 2015;21:671-2.

2. African Centre for Global Health and Social Transformation (ACHEST) U. African Health Leaders. Omaswa F, editor. Oxford: Oxford Univ Press; 2015.

3. World Health Organization. Global status report on alcohol and health. Geneve: WHO; $2014 . I$

4. United Nations. Transforming our world: the 2030 Agenda for Sustainable Development. A/RES/70/1. 2015. [accessed 2019 Oct

22]. Available from: https://sustainabledevelopment.un.org/content/ documents $/ 21252030 \% 20$ Agenda $\% 2$ for $\% 20$ Sustainable $\% 20$ Development\%20web.pdf.

5. GBD 2017 Risk Factor Collaborators. Global, regional, and national comparative risk assessment of 84 behavioural, environmental and occupational, and metabolic risks or clusters of risks for 195 countries and territories, 1990-2017: a systematic analysis for the Global Burden of Disease Stu. Lancet. 2018;392:1923-94.

6. World Health Organization. 2018 World Health Statistics: monitoring 
health for the SDGs, sustainable development goals. Geneve: WHO; 2018.

7. World Health Organization. Sao Tome and Principe Factsheet of Health Statistics 2018. Brazzaville: WHO African Health Obs. 2018:0-21.

8. World Health Organization. Atlas of African Health Statistics 2016. Health Situation Analysis of the African Region.; 2016. [accessed 2019 Oct 22] Available from: https://apps.who.int/iris/bitstream/ handle/10665/206547/9789290232919.pdf?sequence=1\&isAllowed=y.

9. World Health Organization. Regional Office for Africa. Atlas of African Health Statistics 2018: Universal Health Coverage and the Sustainable Development Goals in the WHO African Region.; 2018. [accessed 22 Oct 2019]. Available from: https://apps.who.int/iris/bitstream/hand le/10665/311460/9789290234135-eng.pdf?sequence=1\&isAllowed=y

10. IJsselmuiden CB, Nchinda TC, Duale S, Tumwesigye NM, Serwadda D. Mapping Africa's advanced public health education capacity: The AfriHealth project. Bull World Health Organ. 2007;85:914-22.

11. World Health Organization. Global Status Report on noncommunicable diseases 2014. Geneva: WHO; 2014.

12. Roswall N, Weiderpass E. Alcohol as a risk factor for cancer: existing evidence in a global perspective. J Prev Med Public Health. 2015;48:19.

13. World Cancer Research Fund. Diet, nutrition, physical activity and cancer: a global perspective: the Third Expert Report: physical activity and the risk of cancer. London: WCRF/AICR; 2018.

14. Global T, Observatory C. (https://www.linkedin.com/groups/3713610/ profile) “ (http://www.iarc.fr/en/feeds/index.php) \# (https://twitter.com/ iarcwho). IARC. 2018. http://gco.iarc.fr.

15. International Agency for Research on Cancer. IARC. 2018. [accessed 2019 Oct 22]. Available from: https://www.iarc.fr/cards_page/ iarcrssfeeds/.

16. World Health Organization, Regional Office for Africa. A heavy burden - the indirect cost of illness in AFRICA. 2019. Brazzaville: WHO ROA; 2019.

17. Department of Health. UK Chief Medical Officers' Alcohol Guidelines Review: summary of the proposed new guidelines. London: DH; 2015.

18. Clausen T, Rossow I, Naidoo N, Kowal P. Diverse alcohol drinking patterns in 20 African countries. Addiction. 2009;104: 1147-54.

19. GBD 2017 SDG Collaborators. Measuring progress from 1990 to 2017 and projecting attainment to 2030 of the health-related Sustainable Development Goals for 195 countries and territories: a systematic analysis for the Global Burden of Disease Study 2017. Lancet. 2018;392:2091-138.

20. World Health Organization. Mortality in Sao Tome and Principe. 2008:2008-2010. [accessed 2019 Oct 22]. Available from: http://www. aho.afro.who.int/profiles_information/index.php/Sao_Tome_and Principe:Mortality/pt.

21. Wood AM, Kaptoge S, Butterworth AS, Willeit P, Warnakula S, Bolton $\mathrm{T}$, et al. Risk thresholds for alcohol consumption: combined analysis of individual-participant data for 599912 current drinkers in 83 prospective studies. Lancet. 2018;391:1513-23.

22. Kanteres F, Rehm J, Lachenmeier DW. Artisanal alcohol production in Mayan Guatemala: Chemical safety evaluation with special regard to acetaldehyde contamination. Sci Total Environ. 2009;407:5861-8.

23. Casswell S, Huckle T, Wall M, Yeh LC. International Alcohol Contro Study: Pricing Data and Hours of Purchase Predict Heavier Drinking. Alcohol Clin Exp Res. 2014;38:1425-31.

24. ICF Macro Inc. Resultados dos Biomarcadores do Inquérito de Indicadores Múltiplos ( MICS ) São Tomé e Príncipe: INE STP; 2015.

25. World Health Organization. Sao Tome and Principe. 2010. [accessed 2019 Oct 22]. Available from: https://www.who.int/substance abuse/ publications/global_alcohol_report/profiles/stp.pdf.

26. Centro Nacional de Endemias. São Tomé e Príncipe Relatório Final. São Tomé: CNE; 2016

27. António R, Marinho RT. Dossier Problemas Ligados ao Álcool. Rev Port Clin Geral. 2008;24:293-300.

28. Barrio P, Reynolds J, García-Altés A, Gual A, Anderson P, Rehm J, et al. Social costs ofillegal drugs, alcohol and tobacco in the EuropeanUnion: a systematic review. Eur Addict Res. 2014;49:205-12.

29. World Health Organization - Regional Office for Africa 2008. São Tomé et Principe Enquête STEPS Note de synthèse Sao Tomé et Principe Enquête STEPS Note de Synthèse. Brazzaville: WHO; 2008.

30. World Health Organization Regional office of Africa. São Tomé et Principe Enquête STEPS. Note de synthèse. 2008. [accessed 2019 Oct 22]. Available from: https://www.who.int/ncds/surveillance/steps/2008_ FactSheet_SaoTomeAndPrincipe.pdf.

31. Lachenmeier DW, Taylor BJ, Rehm J. Alcohol under the radar: Do we have policy options regarding unrecorded alcohol? Int J Drug Policy. 2011;22:153-60

32. Vieira PC, Aerts DR de C, Freddo SL, Bittencourt A, Monteiro L. Uso de álcool, tabaco e outras drogas por adolescentes escolares em município do Sul do Brasil. Cad Saude Publica. 2008;24:2487-98.

33. Malta DC, Mascarenhas MD, Porto DL, Duarte EA, Sardinha LM, Barreto SM, et al. Prevalência do consumo de álcool e drogas entre adolescentes: análise dos dados da Pesquisa Nacional de Saúde Escolar. Rev Bras Epidemiol. 2011;14:S136-46.

34. Ray R, Anish PK. Global strategy to reduce the harmful use of alcohol. Indian J Med Res. 2012;135:261.

35. Glasgow RE, Vogt TM, Boles SM. Evaluating the public health impact of health promotion interventions: the RE-AIM framework. Am J Public Health. 1999:89:1322-7.

36. Castells M. Communication, power and counter-power in the network society. Int J Commun. 2007;1:238-266.

37. Fawcett S, Schultz J, Watson-Thompson J, Fox M, Bremby R. Building multisectoral partnerships for population health and health equity. Prev Chronic Dis. 2010;7:A118.

38. Patel V, Flisher AJ, Hetrick S, McGorry P. Mental health of young people: a global public-health challenge. Lancet. 2007:369:1302-13.

39. Rimal RN, Lapinski MK. Why health communication is important in public health. Bull World Health Organ. 2009;87:247.

40. Macleod J, Oakes R, Oppenkowski T, Stokes-lampard H, Copello A, Crome I. et al. How strong is the evidence that illicit drug use by young people is an important cause of psychological or social harm? Methodological and policy implications of a systematic review of longitudinal, general population studies. Drugs Educ Prev Policy. 2004;11:281-297

41. Angell M. The Ethics of clinical research in the Third World. N Engl $J$ Med. 1997;337:847-9

42. Barry M. Ethical considerations of human investigation in developing countries. N Engl J Med. 1988;319:1083-6.

43. Hingson RW, Heeren T, Winter MR. Age at drinking onset and alcohol dependence. Arch Pediatr Adolesc Med. 2006;160:739

44. Vieira DL, Ribeiro M, Romano M, Laranjeira RR. Álcool e adolescentes: estudo para implementar políticas municipais. Rev Saúde Pública. 2007;41:396-403.

45. Pedrosa AA, Camacho LA, Passos SR, Oliviera RV. Consumo de álcoo entre estudantes universitários. Cad Saude Publica. 2011;27:1611-21

46. National Institute of Statistics. Sao Tome and Principe Multiple Indicator Cluster Survey. São Tomé e Príncipe: NIS STP; 2014.

47. Ryan TP. Sample size determination and power. Madrid: John Wiley \& Sons, Inc; 2013

48. Inchley J, Currie D, Vieno A, Torsheim T, Ferreira-Borges C, Weber $\mathrm{MM}$, et al, editors. Adolescent alcohol-related behaviours: trends and inequalities in the WHO European Region, 2002-2014. [accessed 2019 Oct 22]. Available from: http://www.euro.who.int/en/publications/ abstracts/adolescent-alcohol-related-behaviours-trends-andinequalities-in-the-who-european-region,-20022014-2018.

49. Morgan A, Ziglio E. Revitalising the evidence base for public health: an assets model. Promot Educ. 2007;14:17-22.

50. Masters R, Anwar E, Collins B, Cookson R, Capewell S. Return on investment of public health interventions: a systematic review. J Epidemiol Community Health. 2017;71:827-834.

51. Hernandez L, Landi S, Rapporteurs. Roundtable on Health Literacy, Board on Population Health and Public Health Practice. Promoting health literacy to encourage prevention and wellness. Washington: The National Academies Press; 2015.

52. Corcoran N. Designing resources. In: Working on health communication. London: SAGE Publications Ltd; 2011. p. 99-120

53. Lachenmeier DW. Unrecorded and illicit alcohol. Alcohol Eur Union. 2012; 2012:3:29-34

54. Harter LM, Ellingson LL, Yamasaki J, Hook C, Walker T. Defining moments... Telling stories to foster well-being, humanize healthcare, and advocate for change. Health Commun. 2018;00:1-6.

55. Rimal R. Why health communication is important in public health. Bul World Health Organ. 2009;87:247.

56. Labonte R, Laverack G. Capacity building in health promotion, Part 1 : For whom? And for what purpose?. Critical Public Health. 2001;11:111 27.

57. Nutbeam DO. Health literacy as a public health goal : a challenge for contemporary health education and communication strategies into the 21st century. Health Promot Int. 2000:15:259-67.

58. Mabry PL, Olster DH, Morgan GD, Abrams DB. Interdisciplinarity and systems science to improve population health. A view from the $\mathrm{NIH}$ 
Office of Behavioral and Social Sciences Research. Am J Prev Med. 2008;35:S211-24.

59. Pinheiro A, Picanço $P$, Barbeito J. A realidade do consumo de drogas nas populações escolares. Rev Port Clin Geral. 2018;27:348-55.

60. Ezeh AC, Izugbara CO, Kabiru CW, Fonn S, Kahn K, Manderson L, et al. Building capacity for public and population health research in Africa: the consortium for advanced research training in Africa (CARTA) model. Glob Health Action. 2010;3:1.

61. Hofman K, Blomstedt $\mathrm{Y}$, Addei S, Kalage R, Maredza M, Sankoh $\mathrm{O}$, et al. Addressing research capacity for health equity and the social determinants of health in three African countries: the INTREC programme. Glob Health Action. 2013;6:1.

62. Harter LM, Ellingson LL, Yamasaki J, Hook C, Walker T. Defining Moments...Telling Stories to Foster Well-being, Humanize Healthcare, and Advocate for Change. Health Commun. 2020;35:262-7.

63. Rimal R. Why health communication is important in public health. Bull World Health Organ. 2009;87):247.
64. Nutbeam DON. Health literacy as a public health goal : a challenge for contemporary health education and communication strategies into the 21st century. Contemp Health. 2006;15:259-68.

65. Mabry PL, Olster DH, Morgan GD, Abrams DB. Interdisciplinarity and Systems Science to Improve Population Health. A View from the NIH Office of Behavioral and Social Sciences Research. Am J Prev Med. 2008;35: S211-24.

66. Pinheiro A, Picanço P, Barbeito J. A realidade do consumo de drogas nas populações escolares. Rev Port Clin Geral. 2018;27:348-55.

67. Ezeh AC, Izugbara CO, Kabiru CW, Fonn S, Kahn K, Manderson L, et al. Building capacity for public and population health research in Africa: The consortium for advanced research training in Africa (CARTA) model. Glob Health Action. 2010;3.

68. Hofman K, Blomstedt Y, Addei S, Kalage R, Maredza M, Sankoh $\mathrm{O}$, et al. Addressing research capacity for health equity and the social determinants of health in three African countries: The INTREC programme. Glob Health Action. 2013;6:19668. 